UDC $378+81^{\prime} 44$

DOI: $10.33184 /$ bulletin-bsu-2019.3.38

\title{
RATING SYSTEM EFFECTIVENESS AS A BASIS FOR IMPROVEMENT OF HIGHER EDUCATION QUALITY ASSESSMENT IN BASHKIR STATE UNIVERSITY (RUSSIAN FEDERATION) AND KOSTANAY STATE PEDAGOGICAL INSTITUTE (REPUBLIC OF KAZAKHSTAN)
}

\author{
(C) R. R. Lukmanova, T. V. Grigoreva, S. E. Rodionova, J. A. Belova \\ Bashkir State University \\ 32 Zaki Validi Street, 450076 Ufa, Republic of Bashkortostan, Russia.
}

\author{
Phone: +7 (937) 3319690. \\ Email: renata89373319690@gmail.com
}

\begin{abstract}
The paper is focused on the rating system as a key tool for higher education assessment in the Russian Federation and Kazakhstan Republic, viewed through point-rating systems in Bashkir State University (Russia) and Kostanay State Pedagogical Institute (Kazakhstan). The aim of the paper is to elaborate some recommendations and improve the module-rating system in Bashkir State University and point-letter-rating system in Kostanay State Pedagogical Institute. Module-rating system of education and assessment is a complex scope of the phased assessment of the Core disciplines learning level within which structuring of the content of each discipline is made: the whole content is divided into Modules, and regular knowledge evaluation is conducted during the semester. In Kostanay State Pedagogical Institute, the Credit educational technology is based on the choice and student's self-planning of credits as standardized units to estimate the volume of students and instructors' academic work. The examination in the form of a test is obligatory and most preferable here, thus, the assessment objectivity increases. There was carried out a two-sided (Russian - Kazakh) comparative analysis which emphasized strong and weak features of point-rating systems within the establishments in question. The legal base (documents) for learning outcomes assessment of the two institutions and the "Module-rating system of Bashkir State University viewed by instructors" were analyzed.
\end{abstract}

Keywords: Module-rating system of assessment, Bashkir State University, Point-letter-rating system of assessment, Kostanay State Pedagogical Institute, Credit educational technology in Kazakhstan, survey "Module-rating system of Bashkir State University viewed by instructors", selforiented educational approach.

\section{Introduction}

The Russian higher educational system has been modernized since the beginning of the year 2000. To clear up the term itself, let us give the definition of the term Modernization. According to E. Dneprov [1], modernization is a complex renovation of separate educational system points and the educational activity in general in compliance with modern life conditions. Preserving the best traditions of the Russian higher education, these changes concern the content, technologies, and organization of the educational activity with some rudiments of the past.

Higher education modernization is an integrative process and at the same time it is a part of the whole modernization process of the Russian society focused on the development of Innovative Economics. To build and integrate Innovative Economics, Russia needs to elaborate and use new knowledge, competences, management systems, and scientific discoveries which should be transformed into new technologies and production. With reference to the above, it is strategically important for both countries (Kazakhstan and Russia) to maintain 3 tasks: 1) to develop and effectively use independent public Higher education assessment system which enables transitioning from one educational program to another; 2) to involve employers into the educational policy and build the Higher education quality standards taking into account the newest tendencies; 3) to integrate themselves into the global educational area.
Higher education modernization processes both in Russia and Kazakhstan were initiated and implemented under the Bologna process and the Lisbon Strategy and are aimed to make Russian and Kazakhstan BA and MA degrees transferable and compatible both in the internal and global educational/labour markets.

The authors attempt to conduct critical analyses of the Module-rating system (MRS) (Bashkir state University (BSU), Russia) and Point-letter-rating- system (PRLS) (Kostanay State Pedagogical Institute (KSPI), Kazakhstan). On the one hand, both Higher education institutions have the same traditions dating back from the Soviet Union, and these traditions are rather strong even nowadays (for example, a 5-point grading system, discussed below). And on the other hand, it is important to trace the way they passed from the end of the Soviet epoch till modern days.

Speaking about MRS and PRLS, we mean that they are the types of Point-rating system (PRS), because both Russian and Kazakh systems have the same nature but are characterized by several distinctive features (this will be discussed below).

\section{Materials and Methods}

The first step of the study is based on theoretical analysis of special documents (materials) developed and implemented in BSU and KSPI (Statement 1 [2] and Statement 2 [3]) and system of grading accepted in the European Union. The authors conduct a two-sided 
comparison of the point-rating systems by means of this legal base.

Besides, the empirical study was conducted using the method of statistical observation, as well as descriptive research, applied to the survey "Modulerating system of Bashkir State University viewed by instructors".

In the context of this study, the questionnaire ("Module-rating system of Bashkir State University viewed by instructors") designing steps and the content are relevant.

The basic process of the survey ran as follows:

1. To define the research aim, to clarify the strong and weak points of BSU Module-rating system by means of the instructors' Questionnaire single answers and to elaborate recommendations of MRS improvement by means of open-ended questions with detailed answers.

2. To identify the respondents and the Questionnaire sample. There are 15 institutions and faculties in BSU:

Institutes of: Economics, Finance and Business; Institute of Law; the Bashkir Academy of Comprehensive Business Safety and Security; Physics and Technology; of Lifelong Education. Departments of: Chemistry; Biology; Geography; History; Philology; Philosophy and Sociology; Engineering; Psychology; Bashkir Philology and Journalism; Mathematics and Information Technology; Romance and Germanic Philology.

The respondents of the Survey were instructors from all of the departments mentioned above.

3. To design the Questionnaire (the template includes 8 questions).

4. The Survey was carried out for 1 month.

5. The data were analyzed.

The questionnaire "Module-rating system of Bashkir State University viewed by instructors" highlighted various issues connected both with advantages and disadvantages of the MRS with more than one answer possible. To name but a few, there are such questions as 1) whether the instructor is to give the mark automatically by the points obtained; 2) which forms of examination are preferable: oral test, written test, or final control must be provided on the basis of points obtained during a semester; 3 ) what are the reasons for getting bonus points (conference participation, scientific articles, grants and patents obtained, etc.); 4) issues making the system more complicated than it is.

Statistics on the Survey (its results) are represented within Results of the article (part 4).

Moreover, it is also necessary to provide Article glossary in which all the basic terms used in the framework of the problem analyzed are represented.

\section{Article glossary}

Module-rating system (BSU) - scope of measures which intends to provide phased assessment of Core disciplines learning outcomes within which structuring of the content of a discipline is made: the whole con- tent is divided into modules and regular learning outcomes assessment is conducted during the semester.

Module (BSU) - a part of a discipline (scope of topics and sectors) which is logically completed with respect to educational objectives and learning outcomes. At the end of each module, Intermediate assessment of knowledge is conducted. Usually there are 2 or 3 modules within a discipline.

Rating - integral assessment of the results of all types of educational students' activity.

Continuous assessment - assessment of learning outcomes within classroom work and extracurricular work during each module.

Intermediate assessment - checking of overall competences, knowledge, and skills during each semester.

Final performance control is conducted at the very end of the semester. There are two types of FPC in BSU: examination (oral; written; oral-written) and pass/no pass. According to the curriculum, several disciplines have examination for FPC, and students get marks (from 2 to 5), and other disciplines have pass/no pass for FPC; pass/no pass can be differentiated from 2 to 5 too.

Instructor (BSU/KSPI) - a teacher of a university subject, who usually teaches a limited number of classes. Here we use the term "instructor" in its general meaning, not taking into account the staff schedule. Following the staff schedule for instructors within Russian Higher education system is accepted: 1. Assistant has/does not have $\mathrm{PhD}$ degree and responsible for practical courses, usually cannot conduct lectures. 2. Senior Tutor (KSPI) - has PhD degree, responsible for conducting practical courses and sometimes lectures. 3. Associate Professor - has $\mathrm{PhD}$ degree or Doctoral degree (specific for Russia), responsible for conducting practical courses and lectures. 4. Professor - has $\mathrm{PhD}$ degree or Doctoral degree, responsible for conducting practical courses and lectures. Only an instructor who has $\mathrm{PhD}$ degree can teach lessons and become an academic advisor for MA students.

Academic advisor (BSU) - an instructor, who assists a student in his/her growth and development by constructing scientific paper and meaningful educational plans which are compatible with their life goals. Academic advising is a continuous and consistent process which is built upon the basis of frequent, accumulated personal contacts between the advisor and advisee.

Advisor (KSPI) - an instructor who has functions of an academic mentor and assists a student in building his/her learning path and Individual plan. It is a tutor who works as an academic consultant within a certain discipline.

Incentive points (BSU) - according to BSU MRS, extra points (not included into 100 points obtained during a semester) can be given to a student for participation in scientific conferences, publications in scientific journals, participation in contests, Olympiads, etc. 
Student Olympiad (BSU) (specific for Post-Soviet education area) is a type of intellectual competition between students within a certain scientific area; it enables revealing both student's knowledge and his/her ability to use this knowledge within uncommon situation. There are University, Local (Republican), AllRussian and International Olympiads.

Written achievement test (BSU) is a type of knowledge checking, specific for Post-Russian education area. During this test, students answer theoretical questions and do practical tasks within a certain discipline.

Information system (BSU) - BSU local computer net.

Credit educational technology (CET) (KSPI) - a study based on choice and student self-planning learning, using credits as standardized units to estimate the volume of students and instructors' academic work.

Individual plan (IP) (KSPI) - document developed by a student with the help of an advisor and based on the Curriculum. IP contains a list of disciplines, instructors, quantity of credits and academic hours.

Grade point average (GPA) (KSPI) - average assessment of learning outcomes for one academic year according to the individual plan.

\section{Discussion}

To make our study clearer, it is needed to give a definition of the notion Point-Rating system, in terms of 1) assessment system typical for Soviet Higher education, which existed till the beginning of the 21 st century and 2) European Credit Transfer and Accumulation System (ECTS), which is the standard across the European Union. Students can accumulate credits and pass them over to other institutions to continue their studies. According to the ECTS, the following grades of an assessment are applied: A «Excellent» («Outstanding performance with only minor errors»), B «Good» («Above the average standard but with some errors»), C «good», D/E «Pass/Sufficient», «Passable performance, meeting the minimum criteria», $\mathrm{F}$ «Fail», «Considerable further work is required». Both in Russia and Kazakhstan, there is a transformation of 100point grading scale into five-point grading scale, traditionally developed at the beginning of the 20th century in the USSR (tabl. 1).

Table 1

Five-point academic grading system in Kazakhstan Republic and Russian Federation

5 "Excellent" denotes highest distinction and excellent knowledge of a subject

4 "Good" denotes good knowledge of a subject

3 "Satisfactory" denotes a creditable or passing grade

2 "Unsatisfactory" denotes hardly any knowledge, below average, the first level of failing

1 "Very Poor", the lowest possible grade, denotes complete failure and is very rarely used

In theory in Russian higher institutions "Excellent" (5 points) corresponds to A "Excellent” («Outstanding performance with only minor errors») and B "Very Good" ("Excellent"), "Good" (4 points) - C "Good", "Satisfactory" (3 points) - D "Satisfactory" and E "Sufficient", categories "Unsatisfactory" (2 points) are as follows: Fx ("Fail" - some more work required before credit can be awarded) while those who have clearly failed are graded as F ("Fail" - considerable further work is required) [4].

In our opinion, both PRSs are effective tools not only for the students' assessment, but also of the Bachelor and Master students' motivation to work hard during each term to get points before an examination session. However, the detailed analyses revealed several weak points in them. Due to the fact given, the detailed Russian-Kazakhstan PRS comparison was conducted, and the results obtained will help to develop recommendations to enforce both assessment systems.

In particular, Bashkir State University started its phased entry into the European Higher Education Area in the year of 1996 by implementing two educational cycles (Bachelor and Master) and became a participant of the Bologna Process together with other universities. One of the most significant steps of this process was formation and implementation of the Module-rating system in the University in 2011 [5].

Module-rating system of education and assessment is a complex scope of the phased assessment of the Core disciplines learning level within which structuring of the content of each discipline is made: the whole content is divided into Modules and regular evaluating of knowledge is conducted during the semester [2].

Module is a part of a discipline (scope of topics and sectors) which is logically completed in respect of educational objectives and learning outcomes. At the end of each module Intermediate control of knowledge is conducted. Usually there are 2 or 3 modules within a discipline.

According to BSU Statement for the Modulerating system of learning and assessment [2] (hereinafter - Statement 1) MRS enables university to:

1) increase students' motivation within their Core subjects studying;

2) intensify self-guided work of the students, involving them into the process of assessment;

3) improve the level of the educational process organization within the whole university and quality of education by means of its intensification, enhancing tutors' and students' work while updating the content and methods studied.

Rating assessment of each discipline has 100point scale for a semester, is put into the Rating Points Entry Sheet, and has 3 types of control:

1. Continuous assessment (classroom work and extracurricular work control during each Module).

2. Intermediate assessment (checking knowledge and skills overall).

3. Final performance control (conducted at the very end of the semester). There are two types of FPC 
in BSU: examination (oral; written; oral-written) and pass/no-pass (all terms and their definitions can be found within the Article Glossary given in "Materials and methods". According to the Curricula, several disciplines have examination for FPC, and students get marks (from 2 to 5), and other disciplines have pass/no pass for FPC; pass/no pass can be differentiated (from 2 to 5 ) as well.

An instructor should develop a Rating-plan of each discipline she/he has and get it approved in the Sub-faculty meeting. The rating-plan of a discipline is a document containing data on modules, forms and terms for the control and assessment criteria. Each Rating-plan is of the online access and presented to students in the 1 st class.

An instructor can impose penalty points for missed classes, according to the scheme represented by BSU Statement 1 [2], and give incentive points to students for participating in scientific conferences, grants, contents, scientific Olympiads, publications, work with pupils at schools, etc. by adding points (from 1 to 10) to already gained.

As it was mentioned before, those conditions provided by BSU MRS are intended to motivate students to work hard during each semester: if a student obtains the needed points quantity by the Continuous assessment and Intermediate assessment, he/she does not have to take the Final performance control (but in some courses the examination is obligatory).

Thus, according to Statement 1, in the cases when a pass/no pass is a form of Final performance control, an instructor should attest a student who gained 60 points by the Continuous assessment and Intermediate assessment during the semester. More to it, a student's presence during the assessment procedure is not required. If the form of Final performance control is an exam and a student has no less than 45 points by the Continuous assessment and Intermediate assessment, an instructor can give him/her a "Satisfactory" mark without any examination procedure with the consent of the student. In case of no less than 60 points - "Good"; 80 points - "Excellent" (tabl. 2). If a student does not accept the mark given, he/she has to pass the exam. The system of penalties is presupposed by the BSU MRS: a student who has gained less than 35 points within Continuous assessment and Intermediate assessment or missed more than $75 \%$ of classes is not permitted to the exam and is obliged to study the unstudied material himself/herself and be assessed by an instructor in the oral-written form. In that case they gain points within the time limits set by the Dean's Office.

Table 2

Final Performance Control in Bashkir State University (Russia)

\begin{tabular}{|c|c|}
\hline Pass/No Pass & Exam \\
\hline $\begin{array}{l}\text { No less than } 60 \text { points } \\
\text { for the Continuous and } \\
\text { Intermediate assessment }\end{array}$ & $\begin{array}{l}\text {-Less than } 35 \text { points ( } 75 \% \text { lessons missed)- } \\
\text { a student is not permitted to take the } \\
\text { exam. } \\
\text {-No less than } 45 \text { points- "Satisfactory". } \\
\text {-No less than } 60 \text { points- "Good". } \\
\text {-No less than } 80 \text { points - "Excellent". }\end{array}$ \\
\hline
\end{tabular}

The process of the MRS implementation is constantly being monitored and changed by both Scientific Advisory Board, Academic Council of the University, and Academic Councils of the faculties. Consequently, BSU MRS was updated and properly discussed during its implementation into the educational process. For example, at first points for attendance were added to Continuous assessment and Intermediate assessment points. And it appeared that a student was encouraged only by the fact he/she attends a lecture. Now the situation is opposite: points can be taken in case of missed lectures and practical classes.

MRS final examination procedure also had to be changed. Thus, there were such cases when a student obtained the necessary points and claimed to get Excellent, but could not display appropriate knowledge during the exam. Having reached certain results, a student stopped to prepare for the exam and hoped to receive the desirable mark by coming to the Final performance control and typing minimum points needed to reach the level of an excellent rating (for example 75 points obtained are enough to pass the exam adding only 5 points out of 30 possible) [6].

Modern BSU MRS version is more accurate: to get a good mark, you need to gain no less than 15 points out of 30 possible under the Final performance control in the exam added to 60 points gained during the semester. And as for the Excellent mark, it is obligatory to score no less than 20 points out of 30 possible.

Thus, BSU MRS is a significant stage of Russian Higher school modernization which encourages student's work and, at the same time, makes assessment procedure more transparent. It enables students to catch and fully comprehend prospects of his/her work at the beginning of the semester.

It should be noted than Bashkir State University is not the 1st institution which implemented MRS in Russia and it has applied all scope of positive experience from other universities (namely, Russian State University for the Humanities, Gorno-Altaisk State University, Orenburg State University, Tver State Technical University, etc.) to evaluate weak and strong points of the described system [7].

In this regard some experience of foreign colleagues can be extremely useful too; especially from those universities which work within the Post-Soviet area.

For example, special Point-letter rating system (PLRS) is developed and successfully implemented in Kostanay State Pedagogical Institute (KSPI) (Kazakhstan). The aims of this system and BSU MRS coincide.

The Republic of Kazakhstan began its entry into the European Higher Education Area in the year of 2002. It was systematic. However, Kazakhstan joined the Bologna process only in 2010. As a matter of fact, this system should be considered as experimental: several Kazakh Higher education institutions work within Credit educational technology (CET), among them Kostanay State Pedagogical Institute (KSPI). 
According to the "Statement for education process organization under the Credit educational technology in Kostanay State Pedagogical Institute (Bachelor cycle)" (hereinafter - Statement 2) [3], CET is based on the choice and student self-planning with credits as standardized units to estimate volume of students and instructors academic work [3].

Learning in the CET framework is a complex educational phenomenon, undoubtedly effective, but the authors focus not on the CET as a whole, but on the assessment system within it, particularly on the Pointrating-letter assessment system (PRLS). Let us describe just the key CET issues, because the object of our investigation (PRLS) is a tool of its implementation.

According to CET, each curriculum has 3 main parts: 1. Part GD (General Studies). 2. Part BS (Basic Studies). 3. Part M (Specialist Studies). Besides, there is a subdivision into Compulsory and Elective courses. Students can choose their own learning path and build their Individual plan (IP). "IP is a document which is developed by a student with the help of a consultant and is based on the Curriculum; IP contains a list of disciplines, instructors, quantity of credits and academic hours" [4].

Such a phenomenon as the Individual educational student path is an innovation within the Post-Soviet area. In fact, implementation of IP within BA and MA is one of the key measures aiding the Kazakhstan Republic incorporation into the European Higher education area. In this case one can speak of the self-oriented educational approach enabling to reveal student's motives, demands, interests and paying attention to his/her aptitudes. A student learns how to make his/her own choice and becomes more independent and unaided. In our opinion, students' active position towards the educational process provides their faster socialization.

It was noted above that BSU MRS is also focused on student activity stimulation of during a semester, but obviously "degree of freedom" is different in the universities.

Despite the distinct IP advantage, several problems can appear: a 1st year university student, being in fact a school graduate, is sometimes not ready to make his/her own choice and cannot build the education path by himself/herself. Such a problem can be solved by means of an advisor, who helps a student to build IP and develop a learning path.

In the framework of our study the similar terms as academic advisor (accepted in BSU), advisor, and tutor (specific for KSPI) should be differentiated. Academic advisor (BSU) - is an instructor who assists a student in writing a scientific paper and creating meaningful educational plans which are compatible with their life goals. Academic advising is a continuous and consistent process which is built by frequent, accumulated personal contacts between the advisor and the advisee. Effective academic advising is the cornerstone of the University academic programme. Advisor (KSPI) - is an instructor who has functions of an academic mentor and assists a student in building his/her learning path and IP. Tutor (KSPI) is an instructor who works as an academic consultant within a certain discipline [3].

In fact, the scope of duties specific for an academic advisor includes both tutor's and advisor's responsibilities and is attributed to the European education system, but it is more narrow focused as compared to the Russian one.

Let us turn to the assessment system within KSPI CET. Point-rating control in KSPI has three levels: Continuous assessment, Intermediate assessment, and Final performance control, estimated in percent. Student's semester rating consists of Continuous assessment and Intermediate assessment points. Final performance control points include Semester rating and percent, obtained by a student during the examination procedure.

Continuous assessment is a systematic assessment of learning outcomes dealing with certain disciplines. It is conducted by an instructor during practical classes and contains separate questions and tasks. As for the Intermediate assessment, it checks learning outcomes after completed topics and programme sections on the level of generalization, analyses, and links with other topics and is usually provided by a lecturer. Intermediate assessment is carried out within the approved academic calendar during the 8 th and 15 th weeks of academic period.

One should pay attention that the KSPI assessment system is similar to the BSU system, but it has several distinctive features.

As well as in BSU, assessment of the learning outcomes includes three control stages: Continuous assessment, Intermediate assessment, and Final performance control.

The final examination mark depends on the sum of the student's semester rating and percent amount gained during the examination procedure. The final mark consists of the following figures: $60 \%$ being a result of the student's work during the semester and $40 \%$, as a result of the examination.

Continuous and Intermediate assessment in KSPI, as well as in BSU, are conducted in forms of oral interview, long essay, tests, combined interview-test work (oral and written forms of assessment), but the examination procedure within Final performance control is obligatory in KSPI but not in BSU. According to the KSPI documents, the test is the most preferable form of examination, and the second preferable is oral or written exam depending on the discipline itself.

It has already been mentioned that BSU students obtaining enough points within certain disciplines during a semester get a mark ("Excellent", "Good", "Satisfactory"), without passing any exam ("automatically"). Very often good students who got points which correspond to "Good" mark do not want to pass the exam and get more points for "Excellent". Thus, they do not revise the material covered, do not observe material as a whole, and lose an opportunity to improve their communicative skills during the exam procedure. It leads to the undesirable decrease in education quality. 
As for KSPI, the examination is obligatory, and the test is the most preferable form and consequently the objectivity of assessment increases.

It is significant that there are oral and written forms of the exam in addition to the test: They are applied to assess knowledge, skills, and competence within Humanities or Social subject fields, for example Linguistics, Literature, Law, Political science, etc., because the test does not improve and assess communicative competence at all.

KSPI assessment system as a part of final assessment (examination) seems to be well-elaborated and effective enough, because it solves the following topical problems:

1. Students consolidate the obtained material while preparing for the exam and during answering examiner's questions.

2. Objectivity of student's knowledge, skills, and competence assessment, is preserved.

3. Peculiarities of assessment within Humanities and Social studies are considered by means of written and oral forms of the examination procedure.

In our opinion, such experience could be useful for Bashkir State University nowadays.

Let us turn to the KSPI assessment procedure. Points scored by a student on different assessment levels correspond to the scale from $\langle\mathrm{A}\rangle$ to $\langle\mathrm{F}\rangle$ in Kostanay Institute (3). At the end of each academic year Grade Point Average (GPA) is calculated (Formula), and it increases each year and enables university to improve knowledge and skills of students and develop their competences within Specialist subjects.

Table 3

Attestation Grading and Attestation Points Correspondence

\begin{tabular}{c|c|c}
\hline $\begin{array}{c}\text { Attestation } \\
\text { grading }\end{array}$ & $\begin{array}{c}\text { Attestation } \\
\text { percent }\end{array}$ & $\begin{array}{c}\text { Grading according traditional } \\
\text { Russian/Kazakh assessment } \\
\text { system }\end{array}$ \\
\hline A, A- & $30-28$ & Excellent \\
B+, B, B- & $27-22$ & Good \\
C & $21-10$ & Satisfactory \\
F & $9-1$ & Fail
\end{tabular}

Formula. Grade point average (GPA), KSPI

$$
G P A=\frac{K_{1} \cdot U_{1}+K_{2} \cdot U_{2}+\ldots+K_{n} \cdot U_{n}}{K_{1}+K_{2}+\ldots+K_{n}}
$$

$K 1, K 2, \ldots K n$ - volume of a discipline, in credits;

$U 1, U 2, U n$ - final examination points (from 0 to 4);

$n$ - number of disciplines a year.

It is significant that PLRS shows learning outcomes within two forms: letter system (traditional for Europe and some other countries) and traditional for Russia and Post-Soviet area. This automatically increases the coverage zone of KSPI Bachelor and Master diplomas.

If student's GPA is not enough, he/she may have a repeated training course (Summer semester). Thus, in most cases CET enables students not to be sent down, because Summer semester provides an opportunity to continue education. On the one hand, from the point of view of assessment quality, summer semester is a chance to improve results, and, on the other hand, this opportunity can demotivate students to work hard during the semester.

\section{Results}

This part of our scientific paper is devoted to the Survey "Module-rating system in BSU viewed by instructors", which was discussed below within the part "Methods and materials".

First of all, it is needed to describe Questionnaire designing steps and the content.

The survey "Module-rating system of Bashkir State University viewed by instructors" had the following content:

1. 400 questionnaires were distributed to Dean's offices of all 15 BSU institutions and departments.

2. 378 questionnaires with answers were collected in 2 weeks.

3. The survey was anonymous.

4. Questionnaire had 8 questions.

5. Questions 2, 3,6 and 7 had more than one answer.

6. Questions 1, 5, 7, 8 were open-ended.

Let us make analytical review and represent statistics on Survey.

Despite BSU MRS importance and necessity within the modern educational process, it brings about mixed reactions from the University staff: from full agreement with MRS mechanisms and wish to adopt it and use actively to absolute rejection and requirement to cancel it. To define reasons why instructors have such contradicting attitudes, special survey was conducted. Instructors answered the questions in Questionnaire "Module-rating system in BSU from the point of view of instructors", which includes 8 items. 378 instructors answered the Questionnaire questions.

Instructors had an opportunity to choose more than one answer in Questions 2, 3, 6, and 7. Other questions had the only option.

Positive MRS aspects were singled out in $86.5 \%$ of answers: $33.5 \%$ of instructors are convinced that the system motivates students to work hard during a semester; $26 \%$ think that MRS provides transparency of assessment; $17 \%$ consider it intensifies self-guided work of the students involving them into the process of assessment; $9 \%$ believe it is significant that learning material is divided into module parts within each semester.

In our opinion, the questions suggesting extra answers $(3.5 \%)(2,3,6,7)$ are of the great importance for the Survey, and they contain positive feedbacks, e.g.:

- MRS enables instructors to assess objectively and avoid disputable moments and conflicts with students (Institute of Economics, Finance \& Business);

- MRS provides fewer claims from students, related to assessment (Department of Romance and German Philology); 
- MRS gives an opportunity to give mark "automatically" (Department of Romance and German Philology);

- MRS provides clear assessment criteria (Department of Geography);

- MRS intensifies self-guided work of the students (Department of History).

Answers include negative feedbacks too, e.g.:

- MRS complicates the already complex cognitive process of assessment (Department of Romance and German Philology);

- MRS intensifies self-guided work of the students only up to a certain number of points (Institute of Economics, Finance \& Business); Geography);

MRS discourages students (Department of

- MRS increases formalism only (Department of Bashkir Philology and Journalism);

- Students do not get more knowledge, they just work for points (several instructors call this pointmania) (Institute of Physics and Technology, Institute of Law);

- MRS does not motivate students but takes too much of the instructor's time (Institute of Physics and Technology);

- MRS reveals only some fragments of knowledge as opposed to the exam that enables revealing of systematic knowledge (Department of Engineering, Faculty of Philosophy and Sociology);

$10 \%$ of answers indicate that there are no positive moments connected with MRS, and the overall number of dissatisfied respondents $(25 \%)$ work in the Department of Mathematics and Information Technology.

Concerning the question "Should an instructor give a exam mark "automatically" by the points obtained during the semester, or it is necessary to carry out additional check (exam) of student's knowledge?", half of respondents (51\%) answered: An instructor is not to give a mark "automatically" and an oral/written exam is obligatory, because it enables a student to revise the material and helps to improve and assess student's communicative skills and competences". All faculties for Humanities and Engineering agree on it. $34 \%$ of respondents consider that "it depends on the content of a discipline and its subject field". And 15\% insist that an instructor should give a mark "automatically", because points obtained by a student during the semester are the objective measure of his/her knowledge.

We face a different situation with the question "Should an instructor give a pass/no pass mark "automatically" by the points obtained, or it is necessary to carry out some extra check (pass/no pass procedure) of student's knowledge?" Opinions were divided almost equally: $35 \%$ believe that "an instructor is not to give pass/no pass mark automatically, and oral/written assessment procedure is obligatory, because it enables a student to revise the material and helps to improve and assess student's communicative skills"; $32.5 \%$ state that the instructor should give a mark automatically, because points obtained by a student during the semester is the objective indicator of his/her knowledge, skills and competences; $32.5 \%$ consider it depends on a discipline and its subject field.

As for the form of examination procedure, more than a half of respondents (52\%) think that oral-written one is the most effective for assessing student's knowledge, skills, and competences; $27.5 \%$ choose oral exam; $13 \%$ - test; $5 \%$-written form, and 3\% of respondents consider that examination procedure is not needed at all.

\section{Conclusion}

According to the legal base (Statement 1 and Statement 2), analyses of the situation with BSU Module-rating system, KSPI Point-letter-rating system, and the whole situation of their implementation and use, the authors can make following principal recommendations for their improvement:

- BSU Rating-plan of a discipline should reflect 1) concrete competence, 2) types of tasks focused on achieving the competence, 3) assessment criteria for the task and number of points.

- Final performance control: according to the results of Survey, the procedure of examination in BSU should be returned. Basic forms of exam are tests, either oral or written.

- The main notions, principals, properties (e.g. GPA) were borrowed by KSPI from the European assessment system, and this fact increases academic mobility of KSPI students. GPA may be applied in BSU.

- Phenomenon of the summer semester is unique for the Russian educational area. The idea of its implementation in BSU is significant, though there is a problem of its financing (instructors' salaries).

- The Survey showed that BSU should make MRS more transparent for tutors clarifying the objectives, properties, and its tools.

To conduct the overall review of both Modulerating and Point-letter-rating systems of assessment, more surveys are needed. Consequently, our future study of Point-rating systems of assessment is to include 1) a survey "BSU Module-rating system of assessment from viewed by students"; 2) a survey "KSPI Point-letter-rating system of assessment viewed by instructors"; 3) "KSPI Point-letter-rating system of assessment viewed by students". The results of the questionnaires enumerated will be represented in our future publications.

\section{References}

1. Днепров Э. Д. Модернизация российского образования: документы и материалы. М.: ГУ ВШЭ, 2002. 332 c. URL: https://iq.hse.ru/more/education/modernizatsija-rossijskogoobrazovania (дата обращения: 11.08.2016).

2. Положение о модульно-рейтинговой системе обучения и оценки успеваемости студентов БашГУ. Уфа, 2014. 9 с. URL: http://www.bashedu.ru/sites/default/files/polozhenie_o_ mrs.pdf (дата обращения: 10.02.2018). 
3. Положение об организации учебного процесса по кредитной технологии обучения (бакалавриат) в Костанайском государственном педагогическом институте. Костанай, 2013. 30 с.

4. Frolova V. B. Studying the Practice of Performance Assessment and Rating System Implementation in Higher Institutions / V. B. Frolova, O. A. Kalugina, L. S. Artamonova, A. I. Boykov // International Electronic Journal of Mathematics. 2016. Vol. 5, №5. P. 1185-1193. URL: file:///C:/Users/Henry/ Downloads/IEJME_546_article_57a06a424de06.pdf (дата обращения: 08.01.2017).

5. Анкудимова Д. А., Лукманова Р. Р., Щагина О. В. Комплексный характер обучения бакалавров по направлению «Филология», профиль «Прикладная филология» // Вестник Башкирского университета. 2015. Т. 20, №1. С. 214-219.

6. Григорьева Т. В., Лукманова Р. Р., Кифик Н. Ю. Система оценки успеваемости студентов в рамках модернизации высшей школы в России и Казахстане (на примере Башкирского государственного университета и Костанайского государственного педагогического института) // Вестник Башкирского университета. 2016. Т. 21, №13. С. 728-734.

7. Чуев В. Ю., Дубограй И. В., Лоскутникова Л. М. Проблемы использования балльно-рейтинговой системы оценки знаний студентов и возможные пути их устранения // Международный журнал экспериментального образования. 2016. №11. С. 170-172.

8. Ковтун Е. В., Родионова С. Е. Промежуточная и итоговая аттестация при компетентностном подходе: применение инновационных образовательных технологий // Известия Саратовского университета. Сер. Филология. Журналистика. 2013. Т. 13. Вып. 4. С. 109-112.

9. Методические рекомендации по проектированию оценочных средств для реализации многоуровневых образовательных программ ВПО при компетентностном подходе / В. Богословский, Е. Караваева, Е. Ковтун, О. Мелехова, С. Родионова, Тарлыков В., А. Шехонин. М: изд-во МГУ, 2007. 148 с.

10. Родионова А. Е., Родионова С. Е., Григорьева Т. В. Самостоятельная работа студентов-филологов при компетентностном подходе: особенности использования инновационных образовательных технологий // Филология и человек. 2013. №4. С. 181-189.

11. Alshamy A. Credit Hour System and Student Workload at Alexandria University: a possible paradigm shift // Tuning Journal for Higher Education. 2017. №2. P. 277-309.

12. European Credit Transfer and Accumulation System (ECTS). European Commission. Education and Training. URL: https://ec europa.eu/education/resources/european-credit-transferaccumulation-system_en (дата обращения: 02.01.2019).

13. Григорьева Т. В., Лукманова Р. Р., Родионова С. Е. Модульно-рейтинговая система оценки успеваемости студентов Башкирского государственного университета глазами преподавателей: аналитический обзор // Вестник Башкирского университета. 2019. Т. 24, №1. С. 252-258.

Поступила в редакциию 11.08.2019 2. 